\title{
Organometallic Chemistry of Amidate Complexes. Accelerating Effect of Bidentate Ligands on the Reductive Elimination of N-Aryl Amidates from Palladium (II)
}

Ken-ichi Fujita, Makoto Yamashita, Florian Puschmann, Miguel Martinez Alvarez-Falcon, Christopher D. Incarvito, and John F. Hartwig*

Department of Chemistry, Yale University, P.O. Box 208107, New Haven, CT 06520-8107

\section{Supporting Information}

General. Unless noted otherwise, all manipulations were carried out under an inert atmosphere using a nitrogen-filled glovebox. All glassware was oven-dried for approximately $1 \mathrm{~h}$ prior to use. THF, ether, benzene, dichloromethane, and pentane were collected from a solvent purification system containing a $1 \mathrm{~m}$ column of activated alumina. $\mathrm{C}_{6} \mathrm{D}_{6}$, and THF- $\mathrm{d}_{8}$ were dried over sodium benzophenone ketyl and vacuum transferred prior to use. Dichloromethane- $\mathrm{d}_{2}$ was used as received. ${ }^{1} \mathrm{H}$ NMR spectra were obtained on a $400-$ or $500-\mathrm{MHz}$ spectrometer, and chemical shifts were recorded relative to residual protiated solvent. ${ }^{13} \mathrm{C}$ NMR spectra were obtained at 100.6 or $125.8 \mathrm{MHz}$ on a $400-$ or $500-\mathrm{MHz}$ instrument, and chemical shifts were recorded relative to the solvent resonance. Both ${ }^{1} \mathrm{H}$ NMR and ${ }^{13} \mathrm{C}$ NMR chemical shifts are reported in parts per million downfield from tetramethylsilane. ${ }^{31} \mathrm{P}$ NMR spectra were obtained at 161.9 or 202.4 $\mathrm{MHz}$, and chemical shifts are reported relative to $85 \% \mathrm{H}_{3} \mathrm{PO}_{4}$. Elemental analyses were performed by Robertson Microlabs, Inc., Madison, NJ. Xantphos, DPPF, bromobenzene, iodobenzene, and 1,3,5-trimethoxybenzene were commercially available and used as received. Potassium amidate salt was prepared by the reaction of $\mathrm{KH}$ with corresponding amide reagents in THF at room temperature. Kinetic studies conducted with samples heated in an oil bath were conducted with a thermostated bath.

\section{Preparation of (Xantphos)Pd(Ph)(Br) (1)}

$\mathrm{Pd}(\mathrm{dba})_{2}(573.7 \mathrm{mg}, 0.9977 \mathrm{mmol})$ and Xantphos $(578.5 \mathrm{mg}, 0.9998 \mathrm{mmol})$ were placed in a 100 $\mathrm{ml}$ flask. Benzene $(40 \mathrm{~mL})$ and bromobenzene $(2.00 \mathrm{~mL}, 2.99 \mathrm{~g}, 19.0 \mathrm{mmol})$ were added, and the mixture was stirred at $80{ }^{\circ} \mathrm{C}$ for $4 \mathrm{~h}$. After cooling to room temperature, the solution was filtered through Celite. The filtrate was evaporated in vacuum to a volume of $3 \mathrm{~mL}$. Addition of ether $(50 \mathrm{~mL})$ gave a pale-yellow precipitate. The precipitate was filtered, washed with ether, and dried. (679.5 $\mathrm{mg}, 0.8070 \mathrm{mmol}, 81 \%)$.

${ }^{1} \mathrm{H}$ NMR $\left(\mathrm{CD}_{2} \mathrm{Cl}_{2}\right): \delta 7.59(\mathrm{dd}, J=7.6,1.6 \mathrm{~Hz}, 2 \mathrm{H}$, aromatic), 7.34-7.10 (m, 24H, aromatic), 6.53 (brs, $2 \mathrm{H}$, aromatic), 6.27 (t, $J=7.2 \mathrm{~Hz}, 1 \mathrm{H}$, aromatic), 6.10 (t, $J=7.3 \mathrm{~Hz}, 2 \mathrm{H}$, aromatic), 1.78 (s, 6H, Me in xantphos).

${ }^{13} \mathrm{C}\left\{{ }^{1} \mathrm{H}\right\}$ NMR $\left(\mathrm{CD}_{2} \mathrm{Cl}_{2}\right): \delta 156.3,155.0(\mathrm{t}, J=5.5 \mathrm{~Hz}), 134.3,134.1,133.7,131.1,130.8(\mathrm{t}, J=$ $22.0 \mathrm{~Hz}), 129.0,127.2(\mathrm{t}, J=4.6 \mathrm{~Hz}), 126.5,125.9,123.5,121.5(\mathrm{t}, J=21.1 \mathrm{~Hz}), 120.3,35.5$, 27.5.

${ }^{31} \mathrm{P}\left\{{ }^{1} \mathrm{H}\right\}$ NMR $\left(\mathrm{CD}_{2} \mathrm{Cl}_{2}\right): \delta 9.6(\mathrm{~s})$.

Anal. Calcd. for $\mathrm{C}_{45} \mathrm{H}_{37} \mathrm{BrOP}_{2} \mathrm{Pd}$ : C, 64.19; H, 4.43. Found: C, 64.32; H, 4.24. 


\section{Preparation of (Xantphos)Pd(Ph)[N(Ph)(COMe)] (2)}

(Xantphos) $\mathrm{Pd}(\mathrm{Ph})(\mathrm{Br})(\mathbf{1})(137.9 \mathrm{mg}, 0.1638 \mathrm{mmol})$ was placed in a $20 \mathrm{~mL}$ vial. $\mathrm{THF}(4 \mathrm{~mL})$ solution of $\mathrm{KN}(\mathrm{Ph})(\mathrm{COMe})(28.6 \mathrm{mg}, 0.1651 \mathrm{mmol})$ was added, and the mixture was stirred at room temperature for $1.5 \mathrm{~h}$. The solvent was removed in vacuum. THF $(4 \mathrm{~mL})$ was again added, and the solution was filtered through Celite. The solvent of the filtrate was removed in vacuum. Addition of benzene gave a pale-yellow precipitate. Pentane $(15 \mathrm{~mL})$ was added, and the precipitate was filtered, washed with pentane $(10 \mathrm{~mL})$, and dried. (125.7 $\mathrm{mg}, 0.1402 \mathrm{mmol}$, $86 \%$ ).

${ }^{1} \mathrm{H}$ NMR $\left(\mathrm{C}_{6} \mathrm{D}_{6}\right) ; \delta 7.59$ (brs, 7H, aromatic), 7.31 (brs, 2H, aromatic), $7.08(\mathrm{~d}, J=7.5 \mathrm{~Hz}, 2 \mathrm{H}$, aromatic), $6.88(\mathrm{~m}, 17 \mathrm{H}$, aromatic), $6.71(\mathrm{t}, J=7.6 \mathrm{~Hz}, 3 \mathrm{H}$, aromatic), 6.61 (brd, $J=5.4 \mathrm{~Hz}, 2 \mathrm{H}$, aromatic), $6.52(\mathrm{t}, J=7.3 \mathrm{~Hz}, 1 \mathrm{H}$, aromatic), $6.46(\mathrm{t}, J=7.3 \mathrm{~Hz}, 2 \mathrm{H}$, aromatic), $1.76(\mathrm{~s}, 3 \mathrm{H}$, $\mathrm{COMe}), 1.36$ (s, 6H, Me in xantphos).

${ }^{1} \mathrm{H}$ NMR (THF-d 8 ): $\delta 7.70(\mathrm{~d}, J=7.3 \mathrm{~Hz}, 2 \mathrm{H}$, aromatic), 7.42 (brs, 9H, aromatic), 7.27 (t, $J=7.3$ $\mathrm{Hz}, 5 \mathrm{H}$, aromatic), 7.17 (m, 9H, aromatic), 6.98 (brs, 2H, aromatic), 6.84 (brs, 2H, aromatic), 6.76 (brt, 2H, aromatic), 6.67 (brt, 1H, aromatic), 6.41 (brt, 1H, aromatic), 6.31 (m, 3H, aromatic), 1.77 (s, 6H, Me in xantphos), 1.51 (s, 3H, COMe).

${ }^{13} \mathrm{C}\left\{{ }^{1} \mathrm{H}\right\}$ NMR $\left(\mathrm{THF}-\mathrm{d}_{8}\right): \delta 176.3,155.7,154.0(\mathrm{t}, J=18.3 \mathrm{~Hz}), 150.8,136.9,135.5,134.8(\mathrm{t}, J=$ $14.7 \mathrm{~Hz}), 134.1,134.0,130.3,129.6,129.1$ (t, $J=4.6 \mathrm{~Hz}), 128.8,128.5,127.3,126.9$, 125.2, $122.8,122.1,121.8$, one too many aromatic resonances $36.8,30.4,23.1$.

${ }^{31} \mathrm{P}\left\{{ }^{1} \mathrm{H}\right\}$ NMR $\left(\mathrm{C}_{6} \mathrm{D}_{6}\right): \delta 3.6(\mathrm{~s})$.

${ }^{31} \mathrm{P}\left\{{ }^{1} \mathrm{H}\right\}$ NMR $\left(\mathrm{THF}-\mathrm{d}_{8}\right): \delta 3.3(\mathrm{~s})$.

IR (KBr): v(CO) $1684 \mathrm{~cm}^{-1}$.

Anal. Calcd. for $\mathrm{C}_{53} \mathrm{H}_{45} \mathrm{NO}_{2} \mathrm{P}_{2} \mathrm{Pd}$ : C, 71.02; H, 5.06; N, 1.56. Found: C, 71.20; H, 5.03; N, 1.44.

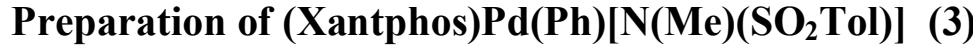

(Xantphos) $\mathrm{Pd}(\mathrm{Ph})(\mathrm{Br})(\mathbf{1})(84.7 \mathrm{mg}, 0.101 \mathrm{mmol})$ and $\mathrm{KN}(\mathrm{Me})\left(\mathrm{SO}_{2} \mathrm{Tol}\right)(126.7 \mathrm{mg}, 0.5673$ mmol) were placed in a $20 \mathrm{~mL}$ vial. Dichloromethane $(5 \mathrm{~mL})$ was added, and the mixture was stirred at room temperature for $5 \mathrm{~h}$. The solvent was removed in vacuum. THF $(10 \mathrm{~mL})$ was added, and the resulting solution was filtered through Celite. The Celite was washed with $6 \mathrm{~mL}$ of THF. The solvent was evaportated from the filtrate in vacuum. Addition of benzene (4 mL) and ether $(12 \mathrm{~mL})$ gave a yellow solution with a small amount of precipitate. This mixture was filtered through Celite, and the solvent was evaporated from the filtrate in vacuum to give a yellow powder. This powder was washed with ether $(8 \mathrm{~mL})$ and pentane $(4 \mathrm{~mL})$, and dried. $(49.5$ $\mathrm{mg}, 0.0523 \mathrm{mmol}, 52 \%$ ). Single crystals for X-ray diffraction were obtained by slow diffusion of pentane into a concentrated THF solution.

${ }^{1} \mathrm{H}$ NMR $\left(\mathrm{C}_{6} \mathrm{D}_{6}\right): \delta 8.12$ (brs, $2 \mathrm{H}$, aromatic), 7.5-6.8 (m, 26H, aromatic), 6.73 (t, $J=7.6 \mathrm{~Hz}, 2 \mathrm{H}$, aromatic), 6.67 (d, $J=7.9 \mathrm{~Hz}, 2 \mathrm{H}$, aromatic), $6.63(\mathrm{~d}, J=6.9 \mathrm{~Hz}, 1 \mathrm{H}$, aromatic), 6.55 (t, $J=7.3$ $\mathrm{Hz}, 2 \mathrm{H}$, aromatic), 1.95 (s, 3H, Tol), 1.65 (brs, 3H, NMe), 1.42 (brs, 6H, Me in xantphos).

${ }^{31} \mathrm{P}\left\{{ }^{1} \mathrm{H}\right\}$ NMR $\left(\mathrm{C}_{6} \mathrm{D}_{6}\right): \delta 1.4$ (brs).

${ }^{31} \mathrm{P}\left\{{ }^{1} \mathrm{H}\right\} \mathrm{NMR}\left(\mathrm{CD}_{2} \mathrm{Cl}_{2}\right): \delta 2.5(\mathrm{br})$.

IR (KBr): v(SO) 1259, $1217 \mathrm{~cm}^{-1}$.

Anal. Calcd. for $\mathrm{C}_{53} \mathrm{H}_{47} \mathrm{NO}_{3} \mathrm{P}_{2} \mathrm{PdS}$ : C, 67.26; H, 5.01; N, 1.48. Found: C, 67.10; H, 4.98; N, 1.47.

\section{Preparation of (Xantphos)Pd(Ph)(Oxazolidinone) (4)}

To the mixture of (Xantphos) $\mathrm{Pd}(\mathrm{Ph})(\mathrm{Br})(\mathbf{1})(248.0 \mathrm{mg}, 0.2945 \mathrm{mmol})$ and the potassium salt of 2-oxazolidinone $(41.5 \mathrm{mg}, 0.332 \mathrm{mmol})$ was added dichloromethane $(10 \mathrm{~mL})$, and the mixture 
was stirred at room temperature for $30 \mathrm{~min}$. The mixture was filtered through Celite, and the solvent was reduced in vacuum to $3 \mathrm{~mL}$. Ether $(15 \mathrm{~mL})$ was layered onto the solution, and the resulting sample was placed in the freezer $\left(-40{ }^{\circ} \mathrm{C}\right)$. Pale-yellow crystals were collected, washed with ether $(15 \mathrm{~mL})$ and dried. $(215.0 \mathrm{mg}, 0.2535 \mathrm{mmol}, 86 \%)$.

${ }^{1} \mathrm{H}$ NMR $\left(\mathrm{CD}_{2} \mathrm{Cl}_{2}\right): \delta 7.78(\mathrm{~d}, J=7.3 \mathrm{~Hz}, 2 \mathrm{H}$, aromatic), 7.52 (s, 2H, aromatic), $7.38(\mathrm{~s}, 4 \mathrm{H}$, aromatic), $7.25(\mathrm{t}, J=7.6 \mathrm{~Hz}, 2 \mathrm{H}$, aromatic), $7.11(\mathrm{t}, J=7.3 \mathrm{~Hz}, 2 \mathrm{H}$, aromatic), 6.98-6.10 (m, $19 \mathrm{H}$, aromatic), 3.27 (brs, $\mathrm{CH}_{2}$ of minor isomer), 2.90 (brs, $\mathrm{CH}_{2}$ of minor isomer), 2.56 (t, $J=$ $8.2 \mathrm{~Hz}, 2 \mathrm{H},-\mathrm{OCH}_{2}$ - of major isomer), 2.41 (brs, $\mathrm{CH}_{2}$ of minor isomer), 2.06 ( $\mathrm{s}, 3 \mathrm{H}, \mathrm{Me}$ in xantphos of major isomer), 1.72 (brs, Me in xantphos of minor isomer), 1.67 (t, $J=8.2 \mathrm{~Hz}, 2 \mathrm{H}$, $\mathrm{NCH}_{2}$ - of major isomer), 1.62 (brs, Me in xantphos of minor isomer), 1.42 (s, 3H, Me in xantphos of major isomer).

${ }^{13} \mathrm{C}\left\{{ }^{1} \mathrm{H}\right\}$ NMR $\left(\mathrm{CD}_{2} \mathrm{Cl}_{2}\right.$, major isomer $): \delta 163.9,156.0,147.1,137.1,135.8,134.9,134.1,133.3$, $131.9(\mathrm{t}, J=20.1 \mathrm{~Hz}), 131.2(\mathrm{t}, J=22.5 \mathrm{~Hz}), 130.3,129.5,128.2,128.0,125.0,123.0,118.9$ (t, $J$ $=20.0 \mathrm{~Hz}), 63.4,47.6,36.8,32.7,23.9$.

${ }^{31} \mathrm{P}\left\{{ }^{1} \mathrm{H}\right\}$ NMR $\left(\mathrm{CD}_{2} \mathrm{Cl}_{2}\right.$ at $\left.0{ }^{\circ} \mathrm{C}\right): \delta 10.7(\mathrm{~d}, J=25.7 \mathrm{~Hz}$, minor cis isomer), 5.1 (s, major trans isomer), $3.2(\mathrm{~d}, J=25.7 \mathrm{~Hz}$, minor cis isomer). Ratio of cis isomer : trans isomer $=20.3: 79.7$. IR (KBr): v(CO) $1675 \mathrm{~cm}^{-1}$.

Anal. Calcd. for $\mathrm{C}_{48} \mathrm{H}_{41} \mathrm{NO}_{3} \mathrm{P}_{2} \mathrm{Pd}$ : C, 67.97; H, 4.87; N, 1.65. Found: C, 67.74; H, 4.91; N, 1.62.

\section{Preparation of (DPPF)Pd(Ph)(I)}

The known complex ${ }^{1}$ was prepared by an alternative convenient method: $\mathrm{Pd}(\mathrm{dba})_{2}(114.7 \mathrm{mg}$, $0.1995 \mathrm{mmol})$ and DPPF (139.0 $\mathrm{mg}, 0.2507 \mathrm{mmol})$ were placed in a small vial. THF (2 mL) and iodobenzene $(0.50 \mathrm{~mL}, 0.91 \mathrm{~g}, 4.5 \mathrm{mmol})$ were added and stirred at room temperature for $1 \mathrm{~h}$. The mixture was filtered through Celite. To the filtrate was added pentane $(10 \mathrm{~mL})$, and the resulting solution was stored in the freezer $\left(-35^{\circ} \mathrm{C}\right)$. Yellow powder formed. The powder was filtered, washed with ether $(10 \mathrm{~mL})$ and dried. (161.5 mg, $0.1867 \mathrm{mmol}, 94 \%) .{ }^{1} \mathrm{H}$ and ${ }^{31} \mathrm{P}\left\{{ }^{1} \mathrm{H}\right\}$ NMR spectra of the product were identical to those reported in the literature. ${ }^{1}$

\section{Preparation of (DPPF)Pd(Ph) [N(Ph)(COMe)] (5)}

To (DPPF)Pd(Ph)(I) $(86.5 \mathrm{mg}, 0.100 \mathrm{mmol})$ was added a solution of $\mathrm{KN}(\mathrm{Ph})(\mathrm{COMe})(17.5 \mathrm{mg}$, $0.101 \mathrm{mmol})$ in THF $(4 \mathrm{~mL})$. The mixture was stirred at room temperature for $30 \mathrm{~min}$. The solution was filtered through Celite. Pentane $(15 \mathrm{~mL})$ was layered onto the solution, and the resulting sample was placed into the freezer $\left(-35^{\circ} \mathrm{C}\right)$. Yellow crystals formed. These crystals were washed with cold ether $(3 \mathrm{~mL})$, and dried. (61.2 $\mathrm{mg}, 0.0702 \mathrm{mmol}, 70 \%)$.

${ }^{1} \mathrm{H}$ NMR $\left(\mathrm{C}_{6} \mathrm{D}_{6}\right)$ : $\delta 8.57$ (br, 2H, Ph), 8.31 (br, 2H, Ph), 7.82 (br, 2H, Ph), 7.06 (br, 19H, Ph), 6.94 (t, $J=7.6 \mathrm{~Hz}, 2 \mathrm{H}, \mathrm{Ph}), 6.73$ (t, $J=7.3 \mathrm{~Hz}, 1 \mathrm{H}, \mathrm{Ph}), 6.57$ (d, $J=7.3 \mathrm{~Hz}, 2 \mathrm{H}, \mathrm{Ph}), 5.28$ (br, 1H, Cp), 4.37 (br, 1H, Cp), 4.12 (br, 1H, Cp), 3.89 (br, 3H, Cp), 3.79 (s, 2H, Cp), 1.59 (s, 3H, $\mathrm{Me})$.

${ }^{31} \mathrm{P}\left\{{ }^{1} \mathrm{H}\right\} \operatorname{NMR}\left(\mathrm{C}_{6} \mathrm{D}_{6}\right): \delta 21.3(\mathrm{~d}, J=27.1 \mathrm{~Hz}), 18.7(\mathrm{~d}, J=27.1 \mathrm{~Hz})$.

IR (KBr): v(CO) $1685 \mathrm{~cm}^{-1}$.

Anal. Calcd. for $\mathrm{C}_{48} \mathrm{H}_{41} \mathrm{FeNOP}{ }_{2} \mathrm{Pd}$ : C, 66.11; H, 4.74; N, 1.61. Found: C, 65.98; H, 4.48; N, 1.54 .

\section{Preparation of $\mathbf{F c P}^{t} \mathbf{B u}_{2}$}

The known compound ${ }^{2}$ was prepared by an alternative method: A solution of bromoferrocene (794.8 $\mathrm{mg}, 3.000 \mathrm{mmol})$ in THF $(10 \mathrm{~mL})$ was cooled to $-78{ }^{\circ} \mathrm{C}$. ${ }^{\mathrm{n}} \mathrm{BuLi}(1.6 \mathrm{M}, 1.88 \mathrm{~mL}, 3.01$ 
mmol) was added, and the solution was stirred at $-78{ }^{\circ} \mathrm{C}$ for $1 \mathrm{~h}$. Di-tert-butylchlorophosphine $(0.570 \mathrm{~mL}, 0.542 \mathrm{~g}, 3.00 \mathrm{mmol})$ was added, and the mixture was slowly warmed to room temperature. Solvent was removed in vacuum, and pentane $(6 \mathrm{~mL})$ was added. This suspension was filtered through a plug of silica-gel, and the silica-gel was washed with $12 \mathrm{~mL}$ of pentane. The filtrate was concentrated to $10 \mathrm{~mL}$ in vacuum. Cooling of the solution at $-35{ }^{\circ} \mathrm{C}$ gave orange crystals. (536.2 mg, $1.624 \mathrm{mmol}, 54 \%$ ). ${ }^{1} \mathrm{H}$ and ${ }^{31} \mathrm{P}\left\{{ }^{1} \mathrm{H}\right\}$ NMR spectra of the product were identical to those reported in the literature. ${ }^{2}$

\section{Preparation of $\left(\mathrm{FcP}^{\mathrm{t}} \mathrm{Bu}_{2}\right) \mathbf{P d}(\mathbf{P h})(\mathrm{I})$}

To $\mathrm{Pd}(\mathrm{dba})_{2}(287.6 \mathrm{mg}, 0.5001 \mathrm{mmol})$ and $\mathrm{FcP}^{\mathrm{t}} \mathrm{Bu}_{2}(200.3 \mathrm{mg}, 0.6065 \mathrm{mmol})$ were added THF $(2 \mathrm{~mL})$ and iodobenzene $(2.0 \mathrm{~mL}, 3.65 \mathrm{~g}, 17.9 \mathrm{mmol})$. The mixture was stirred at room temperature for $10 \mathrm{~min}$. The solvent was concentrated in vacuum to a $2 \mathrm{~mL}$ volume. Pentane (15 $\mathrm{mL})$ was layered onto the resulting solution, and the sample was placed into the freezer $\left(-35^{\circ} \mathrm{C}\right)$. Orange crystals obtained were filtered, washed with ether $(15 \mathrm{~mL})$ and pentane $(10 \mathrm{~mL})$, and dried. (215.4 mg, $0.3362 \mathrm{mmol}, 67 \%$ ).

${ }^{1} \mathrm{H}$ NMR $\left(\mathrm{C}_{6} \mathrm{D}_{6}\right): \delta 7.44$ (d, $\left.J=7.9 \mathrm{~Hz}, 2 \mathrm{H}, \mathrm{Ph}\right), 6.83(\mathrm{t}, J=7.3 \mathrm{~Hz}, 2 \mathrm{H}, \mathrm{Ph}), 6.74(\mathrm{t}, J=6.9 \mathrm{~Hz}$, 1H, Ph), 4.30 (s, 5H, Cp), 4.08 (s, 2H, Cp), 3.89 (s, 2H, Cp), 1.08 (d, J=14.2 Hz, 18H, ${ }^{\mathrm{t}} \mathrm{Bu}$ ).

${ }^{31} \mathrm{P}\left\{{ }^{1} \mathrm{H}\right\}$ NMR $\left(\mathrm{C}_{6} \mathrm{D}_{6}\right): \delta 47.2(\mathrm{~s})$.

Anal. Calcd. for $\mathrm{C}_{24} \mathrm{H}_{32}$ FeIPPd: C, 44.99; H, 5.03. Found: C, 45.09; H, 4.91.

\section{Preparation of $\left(\mathrm{FcP}^{\mathrm{t}} \mathrm{Bu}_{2}\right) \mathbf{P d}(\mathrm{Ph})[\mathbf{N}(\mathrm{Ph})(\mathrm{COMe})](6)$}

To $\left(\mathrm{FcP}^{\mathrm{t}} \mathrm{Bu}_{2}\right) \mathrm{Pd}(\mathrm{Ph})(\mathrm{I})(128.2 \mathrm{mg}, 0.2001 \mathrm{mmol})$ was added a solution of $\mathrm{KN}(\mathrm{Ph})(\mathrm{COMe})(34.8$ $\mathrm{mg}, 0.201 \mathrm{mmol})$ in THF $(4 \mathrm{~mL})$. The mixture was stirred at room temperature for $5 \mathrm{~min}$. The solvent was concentrated in vacuum to a $1 \mathrm{~mL}$ volume. This solution was filtered through Celite. Pentane $(15 \mathrm{~mL})$ was layered onto the resulting solution and the sample was placed into a freezer $\left(-35{ }^{\circ} \mathrm{C}\right)$. Orange crystals formed. The crystals were washed with cold pentane $(4 \mathrm{~mL})$, and dried. (71.1 mg, $0.1097 \mathrm{mmol}, 55 \%)$.

${ }^{1} \mathrm{H}$ NMR $\left(\mathrm{C}_{6} \mathrm{D}_{6}\right): \delta 7.60(\mathrm{~d}, J=7.9 \mathrm{~Hz}, 2 \mathrm{H}, \mathrm{Ph}), 6.96(\mathrm{t}, J=7.6 \mathrm{~Hz}, 2 \mathrm{H}, \mathrm{Ph}), 6.86(\mathrm{t}, J=7.3 \mathrm{~Hz}$, 2H, Ph), 6.79 (t, J=7.6 Hz, 2H, Ph), 6.65 (d, J = 7.6 Hz, 2H, Ph), 4.29 (m, 2H, Cp), 4.01 (s, 5H, $\mathrm{Cp}), 4.00$ (m, 2H, Cp), 1.91 (s, 3H, Me), 1.37 (d, $J=13.9 \mathrm{~Hz}, 18 \mathrm{H}, t \mathrm{Bu})$.

${ }^{31} \mathrm{P}\left\{{ }^{1} \mathrm{H}\right\} \mathrm{NMR}\left(\mathrm{C}_{6} \mathrm{D}_{6}\right): \delta 54.2(\mathrm{~s})$

IR (KBr): v(CO) $1518 \mathrm{~cm}^{-1}$.

Anal. Calcd. for $\mathrm{C}_{32} \mathrm{H}_{40}$ FeNOPPd: C, 59.32; H, 6.22; N, 2.16. Found: C, 59.12; H, 6.32; N, 1.95 .

\section{Preparation of $\left(\mathrm{FcP}^{\mathrm{t}} \mathrm{Bu}_{2}\right) \mathrm{Pd}(\mathrm{Ph})\left[\mathrm{N}(\mathrm{Me})\left(\mathrm{SO}_{2} \mathrm{Tol}\right)\right]$}

To $\left(\mathrm{FcP}^{t} \mathrm{Bu}_{2}\right) \mathrm{Pd}(\mathrm{Ph})(\mathrm{I})(61.1 \mathrm{mg}, 0.0954 \mathrm{mmol})$ was added a suspension of $\mathrm{KN}(\mathrm{Me})\left(\mathrm{SO}_{2} \mathrm{Tol}\right)$ (21.3 mg, $0.0954 \mathrm{mmol})$ in THF (4 mL). The mixture was stirred at room temperature for $5 \mathrm{~min}$. The solvent was concentrated in vacuum to a $1 \mathrm{~mL}$ volume. This solution was filtered through Celite. Pentane $(15 \mathrm{~mL})$ was layered onto the resulting solution, and stored in freezer $\left(-35^{\circ} \mathrm{C}\right)$. Yellow-orange crystals formed. These crystals were washed with cold ether $(4 \mathrm{~mL})$, and dried. (49.1 mg, $0.0703 \mathrm{mmol}, 74 \%$ ).

${ }^{1} \mathrm{H}$ NMR $\left(\mathrm{C}_{6} \mathrm{D}_{6}\right): \delta 8.30(\mathrm{~d}, J=8.2 \mathrm{~Hz}, 2 \mathrm{H}, \mathrm{Tol}), 7.63(\mathrm{~d}, J=7.9 \mathrm{~Hz}, 2 \mathrm{H}, \mathrm{Tol}), 6.96(\mathrm{~m}, 4 \mathrm{H}, \mathrm{Ph})$, $6.86(\mathrm{t}, J=7.3,1 \mathrm{H}, \mathrm{Ph}), 4.25$ (s, 2H, Cp), 4.05 (s, 5H, Cp), 4.01 (s, 2H, Cp), 2.23 (d, J=2.8 Hz, $3 \mathrm{H}, \mathrm{NMe}), 1.95$ (s, 3H, Tol), 1.26 (d, $\left.J=13.6 \mathrm{~Hz}, 18 \mathrm{H},{ }^{\mathrm{t}} \mathrm{Bu}\right)$.

${ }^{31} \mathrm{P}\left\{{ }^{1} \mathrm{H}\right\} \mathrm{NMR}\left(\mathrm{C}_{6} \mathrm{D}_{6}\right): \delta 54.6(\mathrm{~s})$

IR (KBr): $v(\mathrm{SO}) 1259 \mathrm{~cm}^{-1}$. 
Anal. Calcd. for $\mathrm{C}_{32} \mathrm{H}_{42} \mathrm{FeNO}_{2} \mathrm{PPdS}$ : C, 55.06; H, 6.07; N, 2.01. Found: C, 55.10; H, 6.11; N, 1.86.

Reductive Elimination Reactions of (Xantphos)Pd(Ph)[N(Ph)(COMe) (2), (Xantphos)Pd(Ph)[N(Me)(SO $\left.\left.\mathrm{SO}_{2} \mathrm{Tol}\right)\right] \quad$ (3), (Xantphos)Pd(Ph)(Oxazolidinone) (4), and (DPPF)Pd(Ph)[N(Ph)(COMe)] (5)

Into a small vial were placed the palladium amidate complex $(10.0 \mu \mathrm{mol})$, phosphine ligand $(2$ or 8 equiv), and 1,3,5-trimethoxybenzene $(10.0 \mu \mathrm{mol}) . \mathrm{C}_{6} \mathrm{D}_{6}(0.50 \mathrm{~mL})$ was added via syringe. The mixture was transferred to an NMR tube equipped with a screw cap and a Teflon seal. The vial was washed with $\mathrm{C}_{6} \mathrm{D}_{6}(0.10 \mathrm{~mL} \times 2)$ and washing was also added to the NMR tube. The sample was placed into a thermostated oil bath at 90 or $110{ }^{\circ} \mathrm{C}$ to start the reaction. At fixed intervals, the sample was removed from the oil bath, cooled by immersing in cold water, and a ${ }^{1} \mathrm{H}$ NMR spectrum was measured at room temperature. The yield of the reductive elimination product was determined by ${ }^{1} \mathrm{H}$ NMR analysis using 1,3,5-trimethoxybenzene as an internal standard. The results are shown in Figures S5-S9.

\section{Reductive Elimination Reactions of $\left(\mathrm{FcP}^{t} \mathrm{Bu}_{2}\right) \mathrm{Pd}(\mathrm{Ph})[\mathrm{N}(\mathrm{Ph})(\mathrm{COMe})] \quad$ (6) and $\left(\mathrm{FcP}^{\mathrm{t}} \mathrm{Bu}_{2}\right) \mathrm{Pd}(\mathrm{Ph})\left[\mathrm{N}(\mathrm{Me})\left(\mathrm{SO}_{2} \mathrm{Tol}\right)\right](7)$}

Into a small vial were placed the palladium amidate complex $(10.0 \mu \mathrm{mol})$, phosphine ligand (2 equiv), and 1,3,5-trimethoxybenzene $(10.0 \mu \mathrm{mol}) . \mathrm{C}_{6} \mathrm{D}_{6}(0.70 \mathrm{~mL})$ was added via syringe. The mixture was transferred to an NMR tube equipped with a screw cap and a Teflon seal. The sample was placed into a thermostated oil bath to start the reaction. After complete decomposition of the starting complex was confirmed by ${ }^{31} \mathrm{P}$ NMR, the yield of the reductive elimination product was determined by ${ }^{1} \mathrm{H}$ NMR analysis using 1,3,5-trimethoxybenzene as an internal standard. 


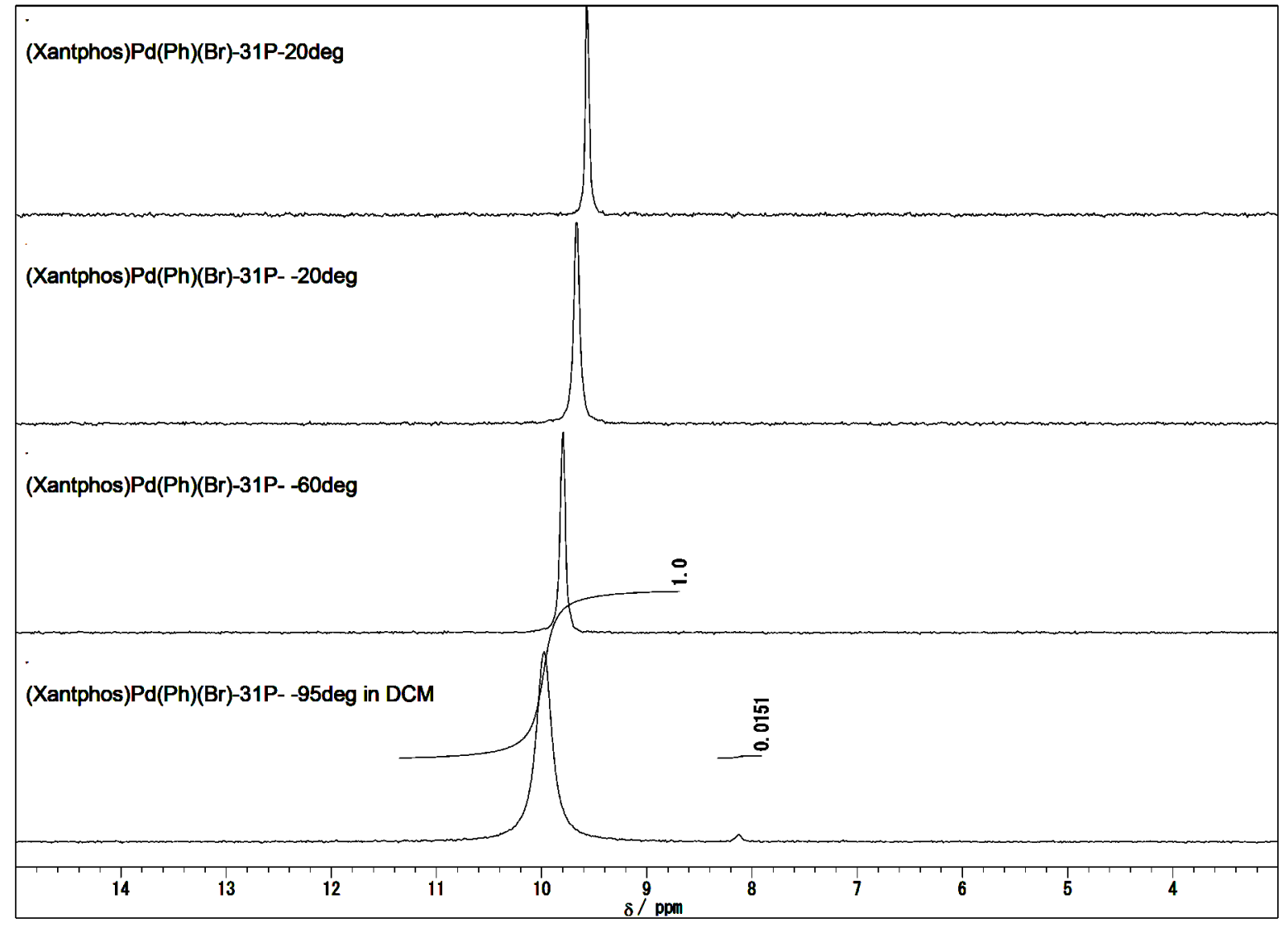

Figure S1. Variable temperature ${ }^{31} \mathrm{P}\left\{{ }^{1} \mathrm{H}\right\}$ NMR spectrum of (Xantphos) $\mathrm{Pd}(\mathrm{Ph})(\mathrm{Br})$ (1) in dichloromethane- $d_{2}$. At $-95{ }^{\circ} \mathrm{C}$, one of the signals for the cis isomer apparently overlaps with the large signal of the trans isomer. 


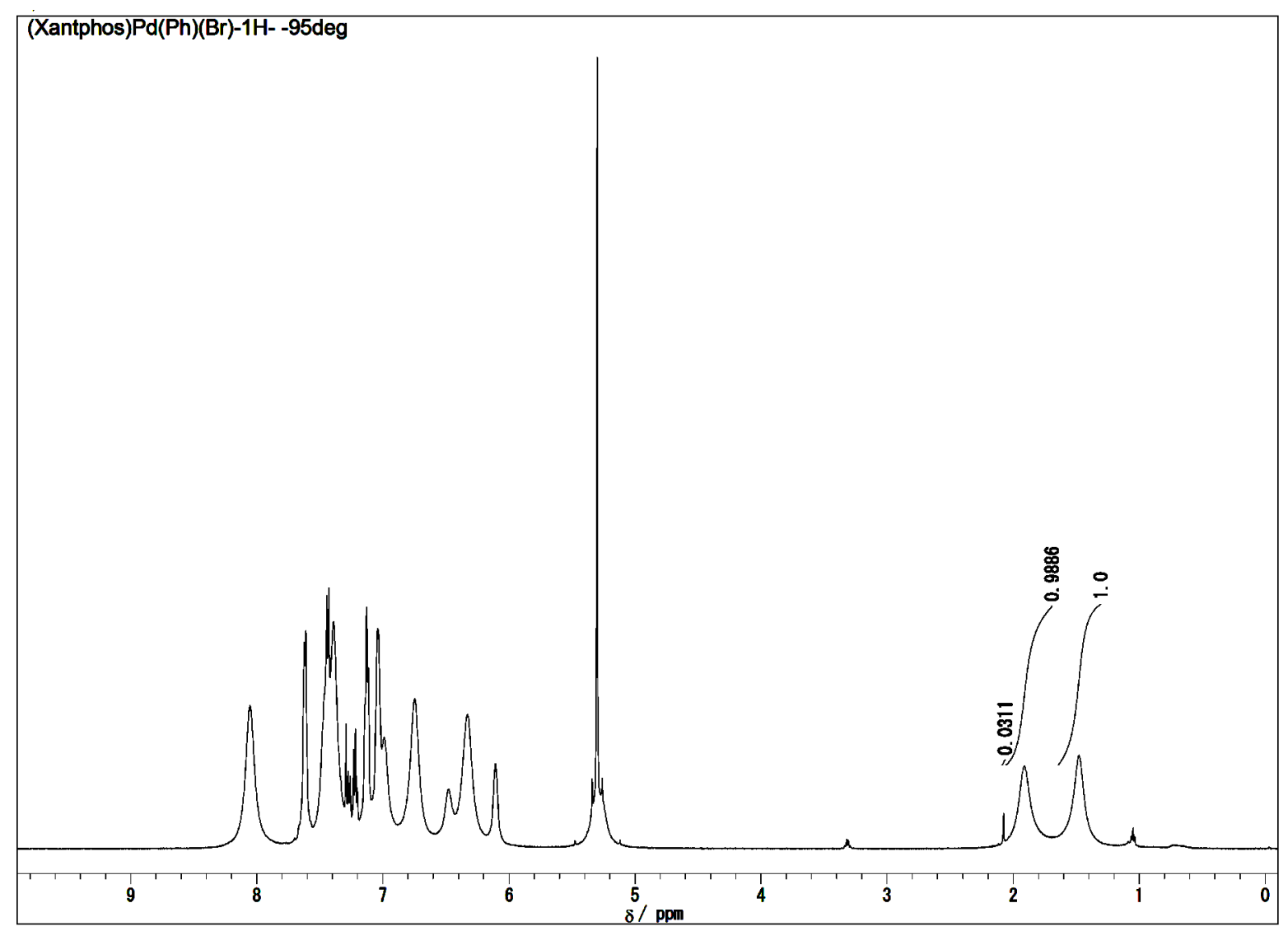

Figure S2. ${ }^{1} \mathrm{H}$ NMR spectrum of (Xantphos) $\mathrm{Pd}(\mathrm{Ph})(\mathrm{Br})(\mathbf{1})$ in dichloromethane- $d_{2}$ at $-95{ }^{\circ} \mathrm{C}$. 


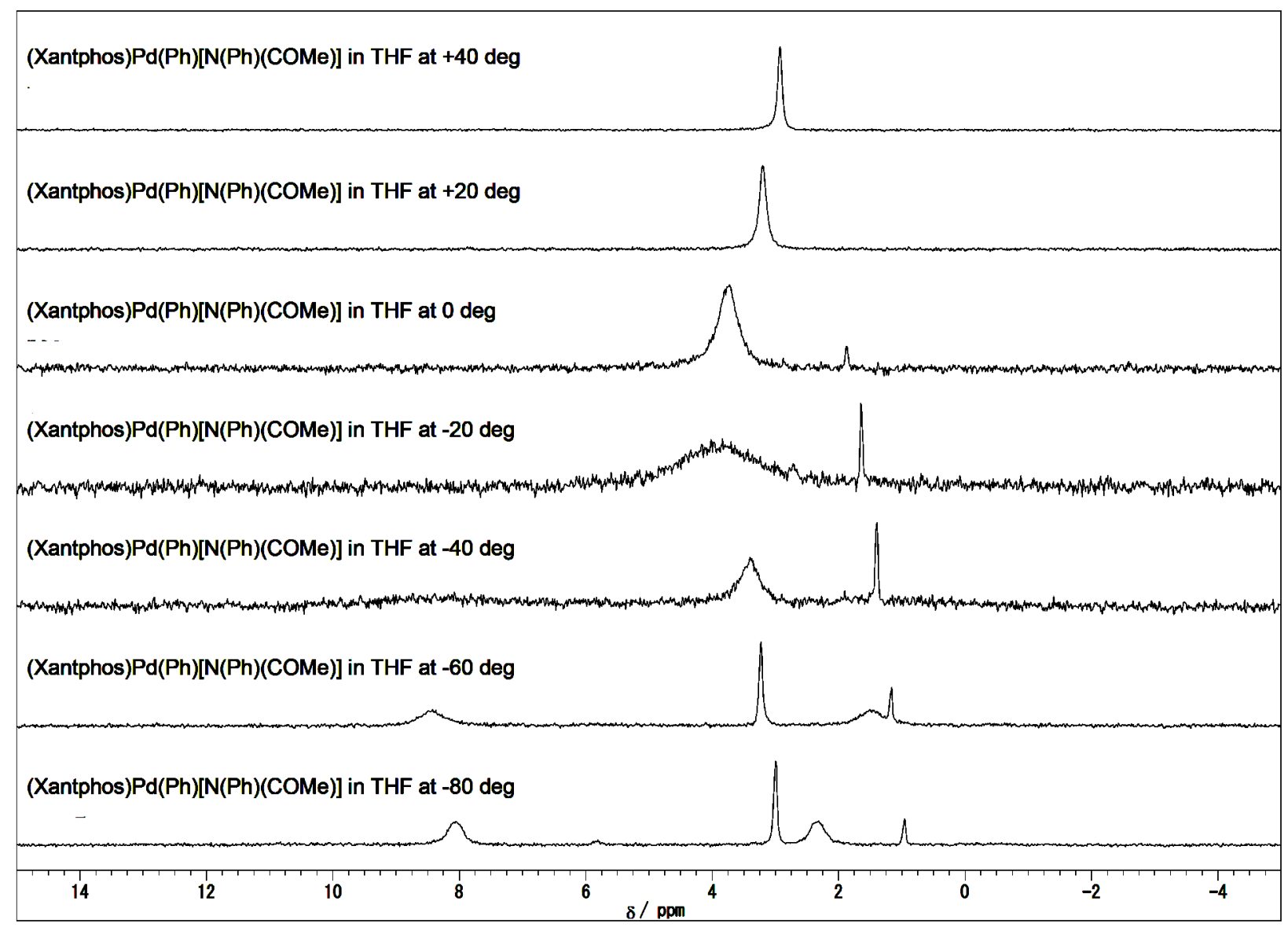

Figure S3. Variable temperature ${ }^{31} \mathrm{P}\left\{{ }^{1} \mathrm{H}\right\}$ NMR spectrum of (Xantphos) $\mathrm{Pd}(\mathrm{Ph})[\mathrm{N}(\mathrm{Ph})(\mathrm{COMe})]$ (2) in THF. At $-80{ }^{\circ} \mathrm{C}$, signals at 8.1 and $2.3 \mathrm{ppm}$ correspond to the cis isomer, and signals at 3.0 and $1.0 \mathrm{ppm}$ can be assigned to rotomers of trans isomer. 


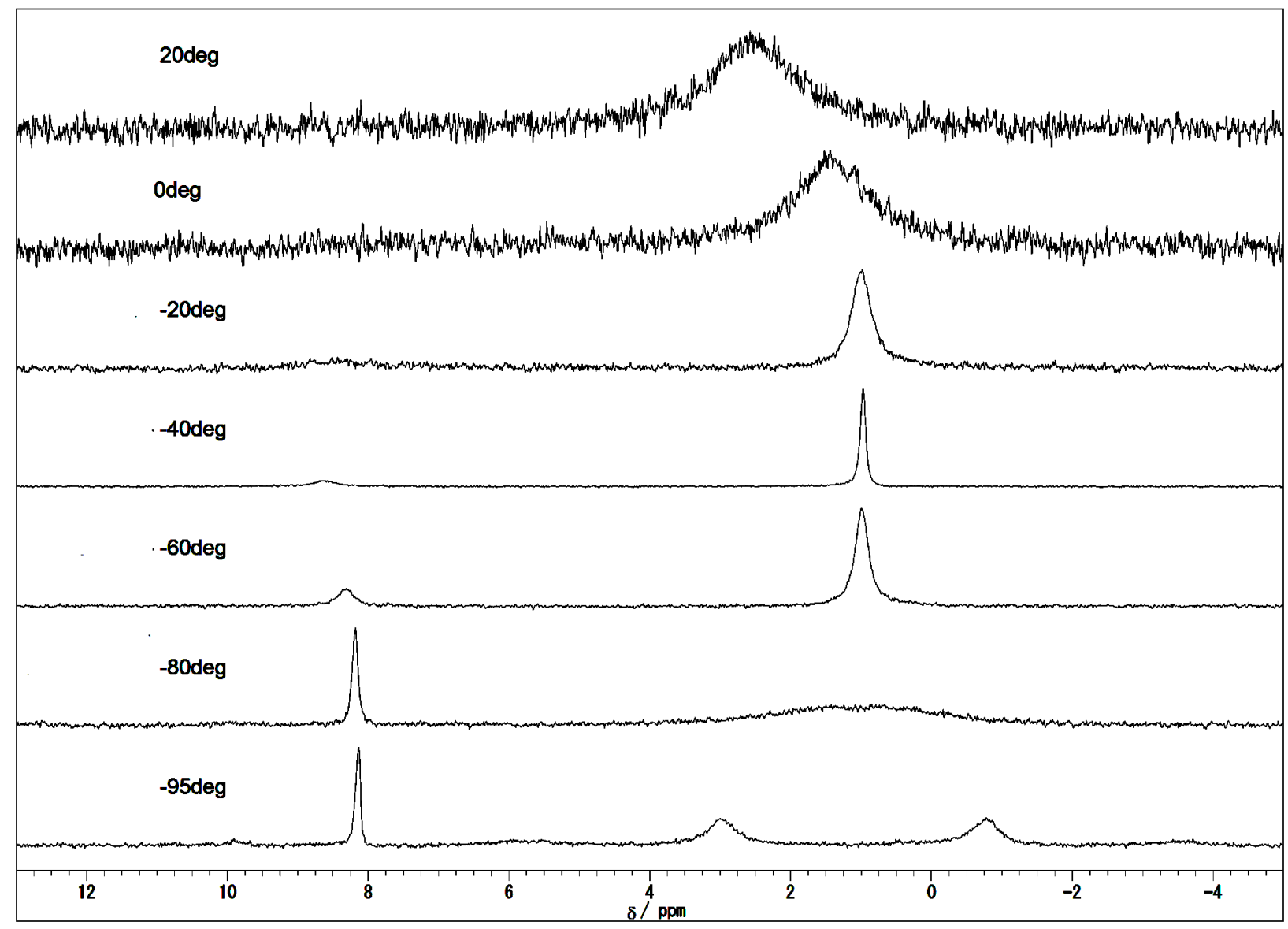

Figure S4. Variable temperature ${ }^{31} \mathrm{P}\left\{{ }^{1} \mathrm{H}\right\}$ NMR spectra of (Xantphos) $\mathrm{Pd}(\mathrm{Ph})\left[\mathrm{N}(\mathrm{Me})\left(\mathrm{SO}_{2} \mathrm{Ph}\right)\right](3)$ in dichloromethane. 


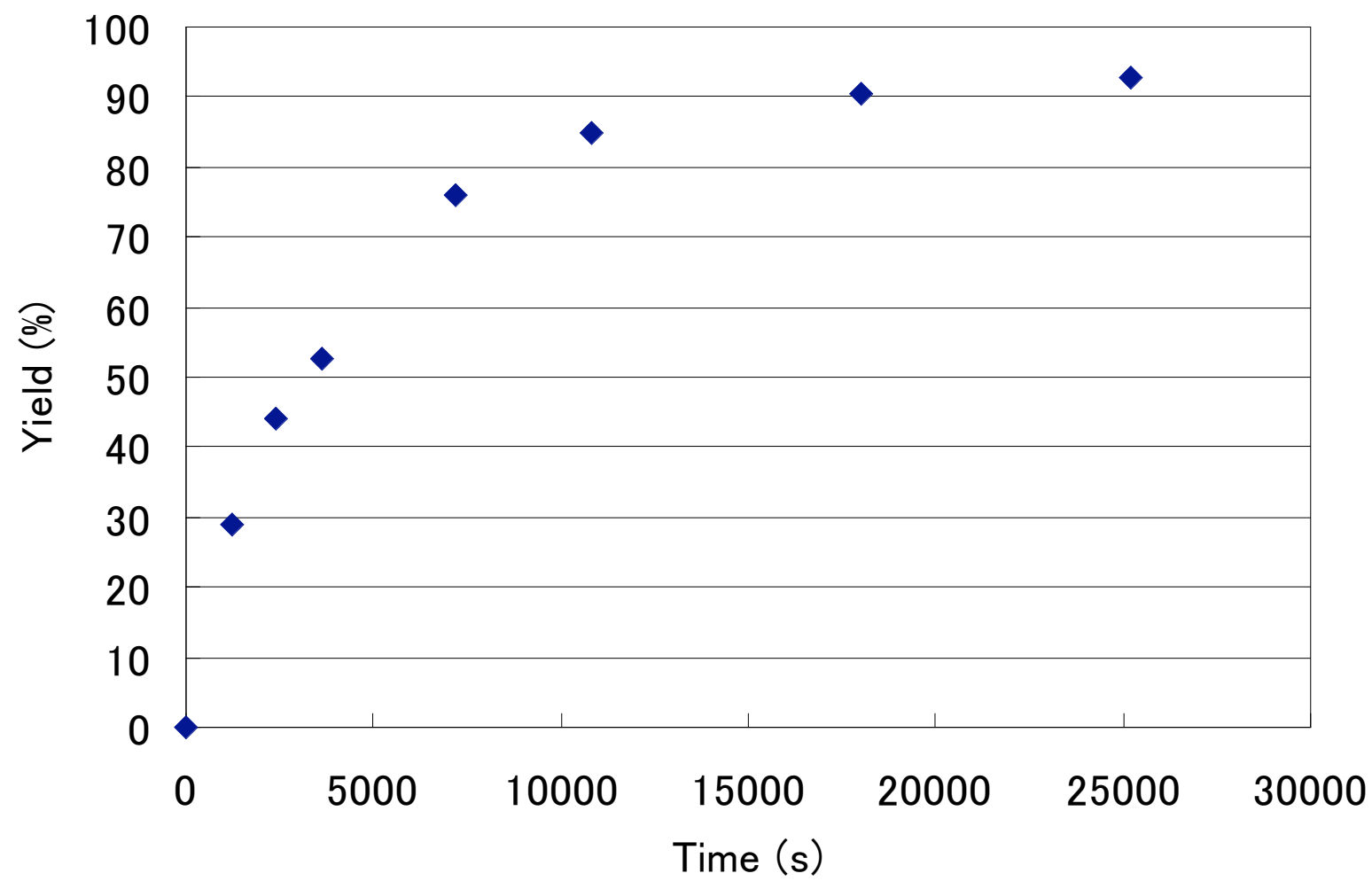

Figure S5. Kinetic plot of the reductive elimination reaction of 2 in the presence of 2 equiv of Xantphos. Curve fitting of the plot gave an equation $y=-a * \exp (-b * x)+c(a=89.3 \pm 2.49, b=$ $0.00025 \pm 0.0000177, \mathrm{c}=91.6 \pm 1.68)$ with $\mathrm{R}^{2}=0.996$. 


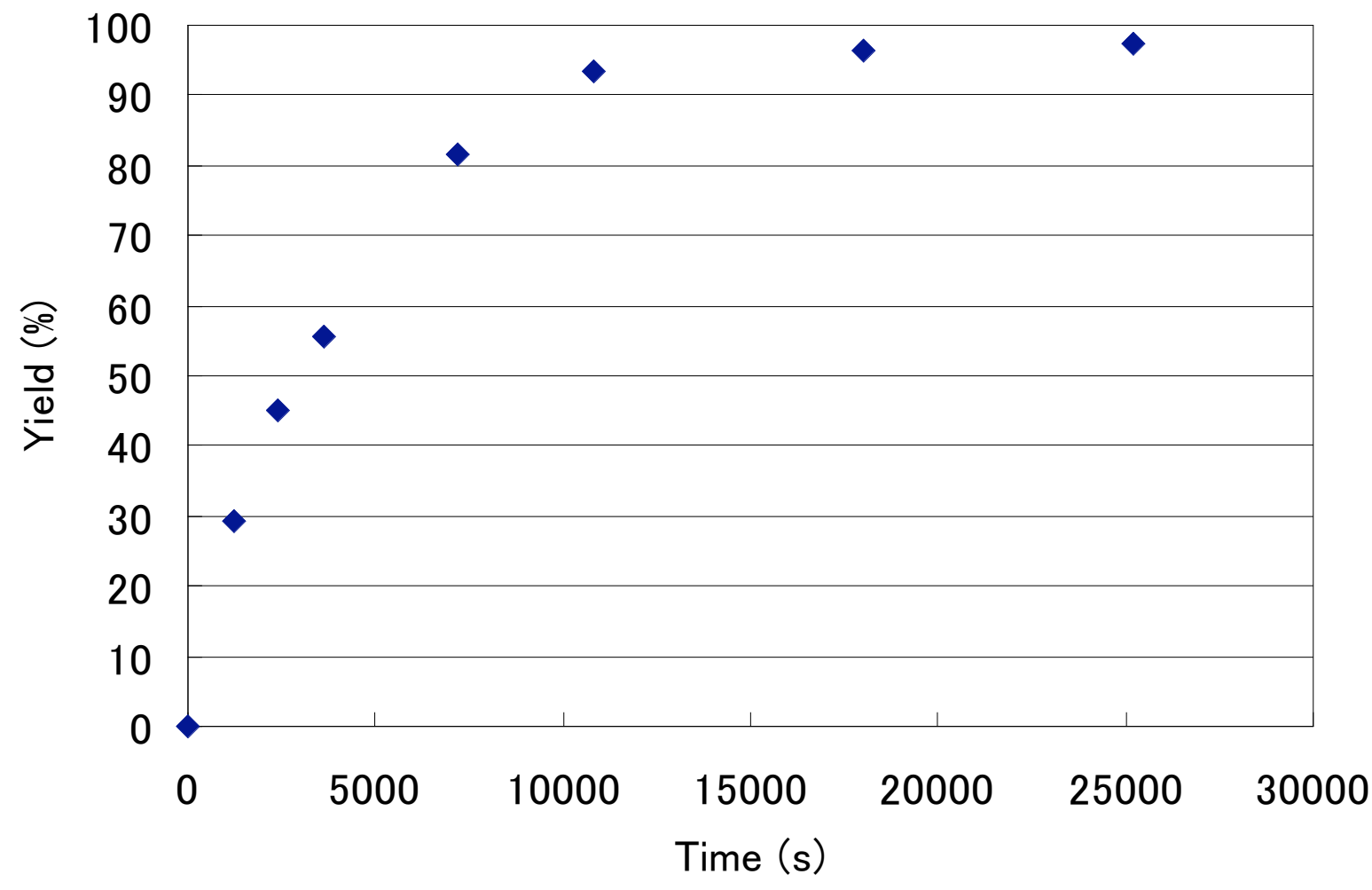

Figure S6. Kinetic plot of the reductive elimination reaction of 2 in the presence of 8 equiv of Xantphos. Curve fitting of the plot gave an equation $y=-a^{*} \exp \left(-b^{*} x\right)+c(a=96.7 \pm 2.23, b=$ $0.000248 \pm 0.0000145, \mathrm{c}=98 \pm 1.5)$ with $\mathrm{R}^{2}=0.997$. 


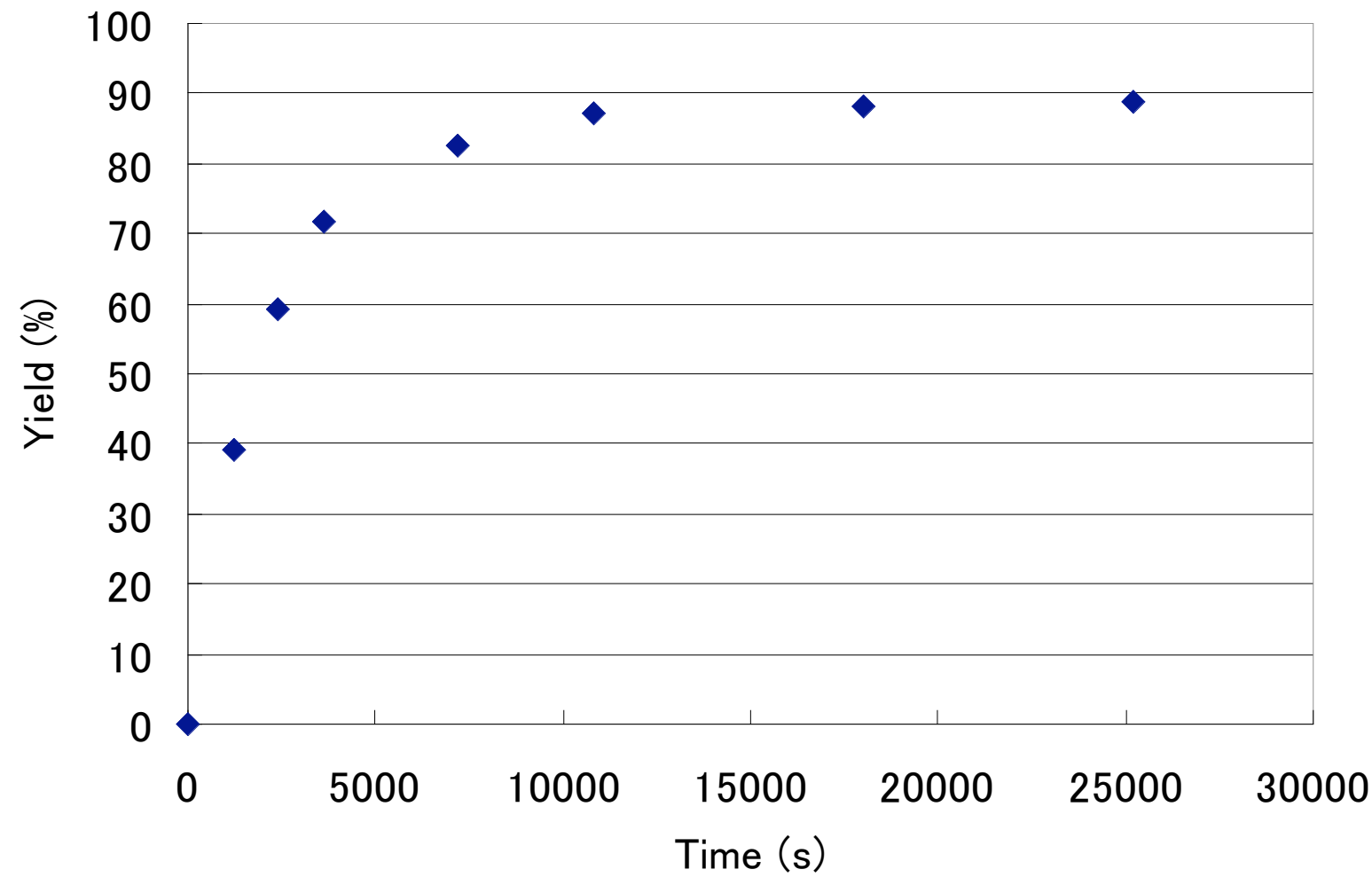

Figure S7. Kinetic plot of the reductive elimination reaction of 3 in the presence of 2 equiv of Xantphos. Curve fitting of the plot gave an equation $\mathrm{y}=-\mathrm{a}^{*} \exp \left(-\mathrm{b}^{*} \mathrm{x}\right)+\mathrm{c}(\mathrm{a}=87.2 \pm 1.32, \mathrm{~b}=$ $0.000471 \pm 0.0000159, \mathrm{c}=87.6 \pm 0.671)$ with $\mathrm{R}^{2}=0.999$. 


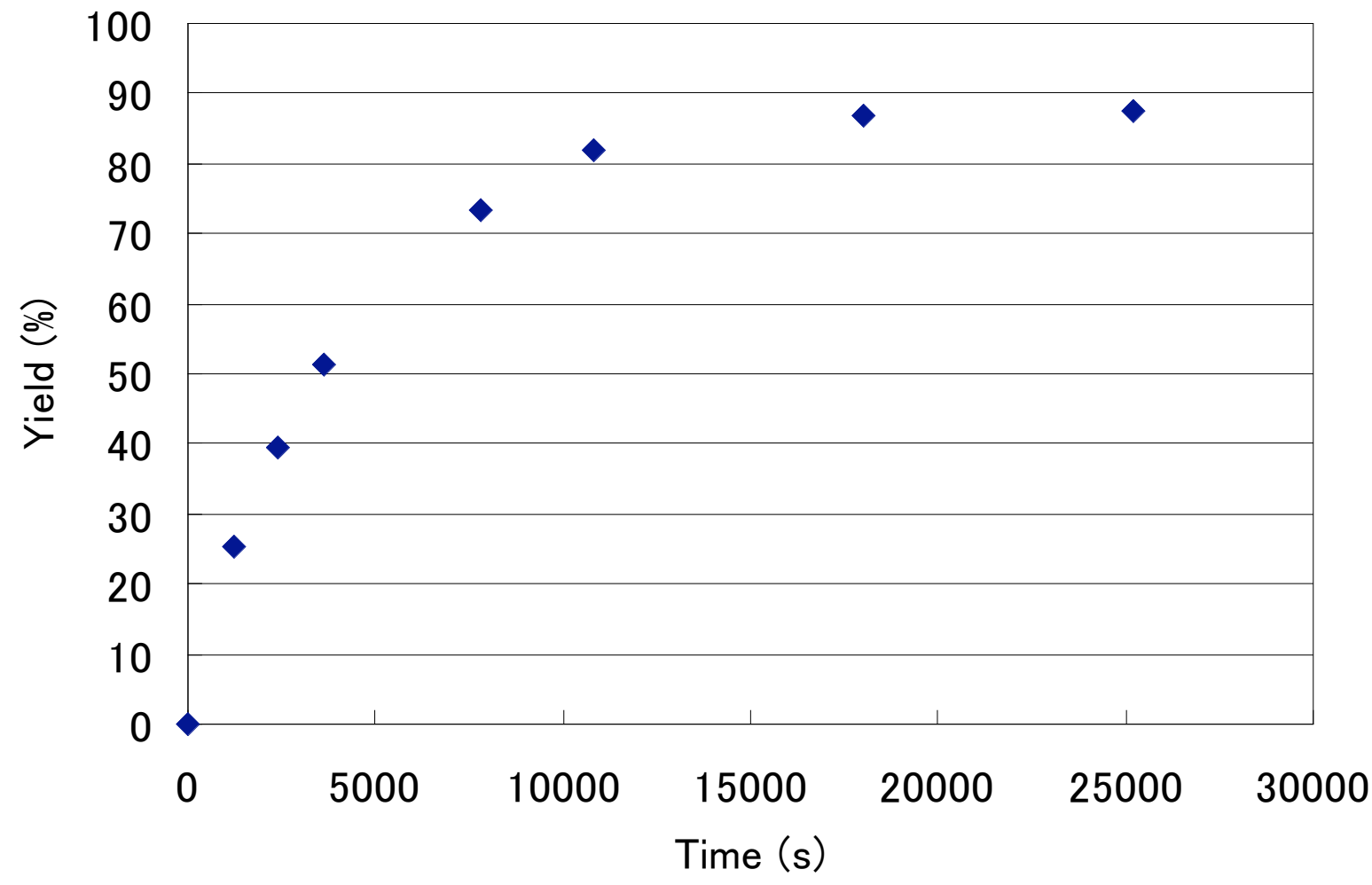

Figure S8. Kinetic plot of the reductive elimination reaction of 4 in the presence of 2 equiv of Xantphos. Curve fitting of the plot gave an equation $\mathrm{y}=-\mathrm{a}^{*} \exp \left(-\mathrm{b}^{*} \mathrm{x}\right)+\mathrm{c}(\mathrm{a}=86.4 \pm 1.33, \mathrm{~b}=$ $0.000245 \pm 0.00000977, \mathrm{c}=87.5 \pm 0.902)$ with $\mathrm{R}^{2}=0.999$. 


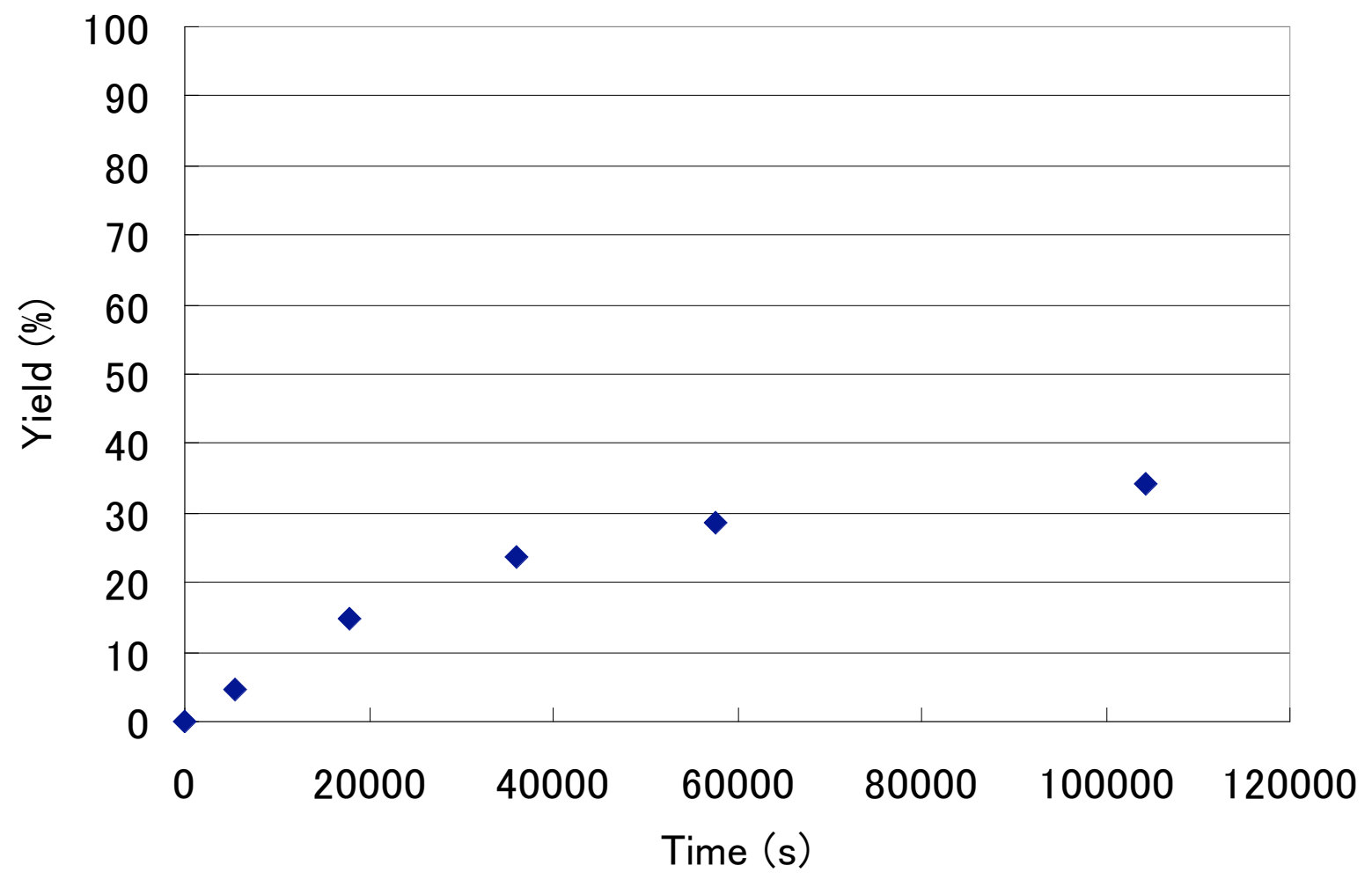

Figure S9. Kinetic plot of the reductive elimination reaction of 5 in the presence of 2 equiv of DPPF. Curve fitting of the plot gave an equation $\mathrm{y}=-\mathrm{a}^{*} \exp \left(-\mathrm{b}^{*} \mathrm{x}\right)+\mathrm{c}(\mathrm{a}=35.8 \pm 0.8, \mathrm{~b}=$ $0.0000298 \pm 0.00000178, \mathrm{c}=35.6 \pm 0.784)$ with $\mathrm{R} 2=0.999$. 


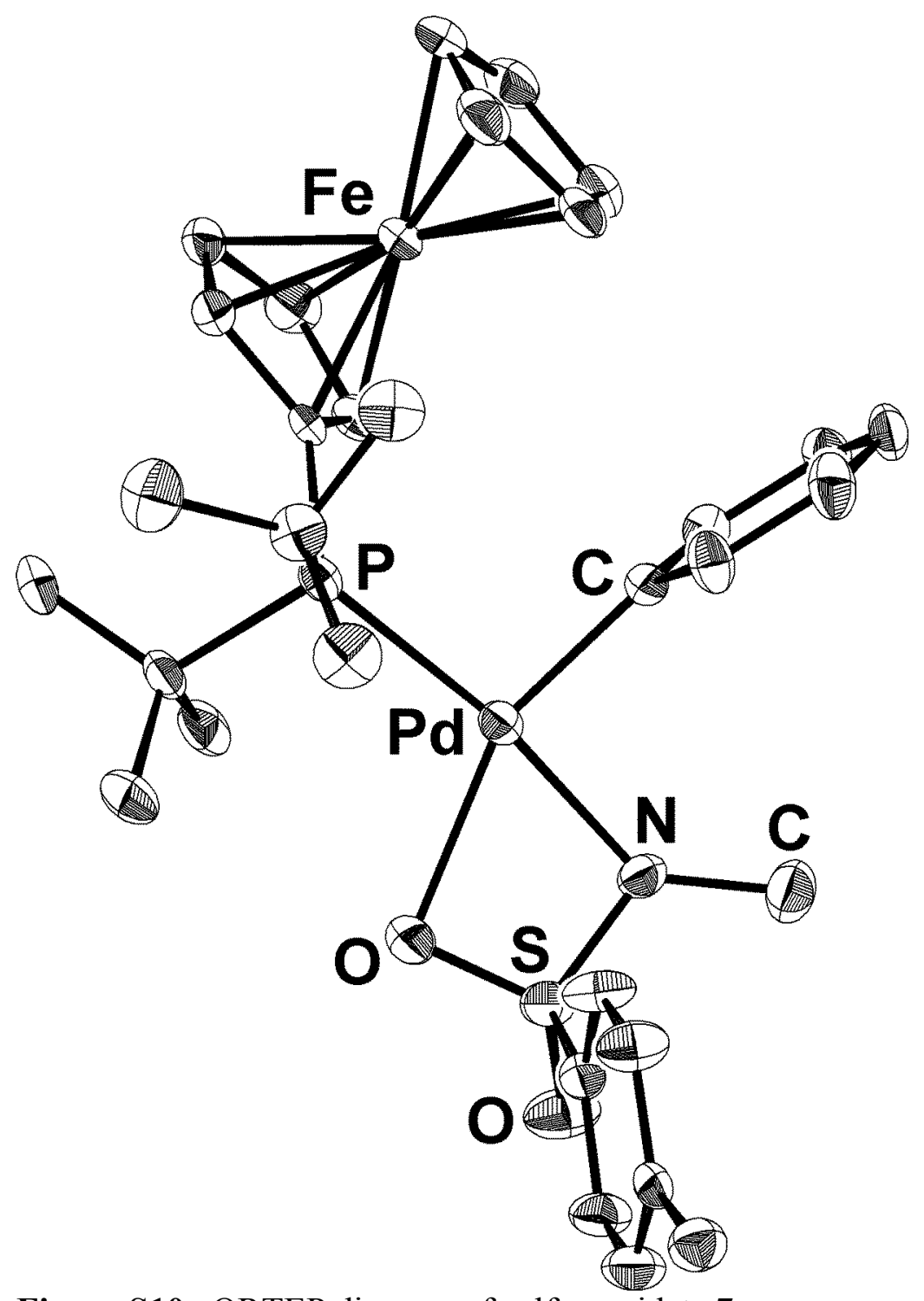

Figure S10. ORTEP diagram of sulfonamidate 7. 


\section{References}

1. J. M. Brown, P. J. Guiry, Inorg. Chim. Acta 1994, 220, 249.

2. N. Kataoka, Q. Shelby, J. P. Stambuli, J. F. Hartwig, J. Org. Chem. 2002, 67, 5553. 